\title{
Quick Of Blood dan Ultrafiltrasi Terhadap Nilai Ureum Pada Pasien Hemodialisis
}

\author{
Ita Ulva Hanivah ${ }^{1}$, Santi Herlina ${ }^{2}$ \\ ${ }^{1,2}$ Fakultas Ilmu Kesehatan Universitas Pembangunan Nasional Veteran Jakarta \\ Jalan Limo Raya Kelurahan Limo Kecamatan Limo Kota Depok \\ Telp. 021-7532884, Fax 021-7546772 \\ Email : santiherlina@upnvj.ac.id
}

\begin{abstract}
Abstrak
Pasien dengan hemodialisis (HD) perlu dinilai untuk perlekatan HD mereka secara berkala. Salah satu parameter kecukupan aksi HD adalah mengukur nilai-nilai Ureum untuk mengetahui rasio reduksi Ureum (RRU). Tujuan dari penelitian ini adalah untuk mengetahui hubungan quick of blood (QB) dan ultrafiltration (UF) dengan nilai urea pada pasien hemodialisis di Klinik Khusus Hemodialisa Sahabat Keluarga. Penelitian ini dilakukan pada 68 responden (accidental sampling) menggunakan data rekam medis dan ditulis pada kuesioner. Hasil pengukuran pertama diketahui bahwa hubungan QB dengan nilai ureum post HD memiliki hubungan yang lemah dan pola negatif $(\mathrm{r}=0,049)$, dan $\mathrm{P}$ Value 0,034 ( $\alpha$ 0,05), sehingga dapat disimpulkan bahwa ada QB hubungan dengan nilai ureum. Pada analisis pengukuran kedua, hasil hubungan QB dengan nilai ureum post HD memiliki korelasi yang lemah dan negatif ( $\mathrm{r}=$ $0,187)$, dan pengukuran kedua adalah nilai P $0,127(\alpha 0,05)$, sehingga dapat disimpulkan ada tidak ada hubungan QB dengan nilai ureum. Hasil pengukuran pertama diketahui bahwa hubungan UF dengan nilai ureum post HD memiliki hubungan yang lemah dan pola negatif $(r=0,220)$, dan Nilai P $0,071(\alpha 0,05)$ tidak menemukan hubungan UF dengan nilai ureum. Pada pengukuran kedua, hasil hubungan UF dengan nilai ureum post HD memiliki hubungan sedang dan negatif $(r=0,335)$, dan pengukuran kedua adalah nilai P $0,005(\alpha 0,05)$, direkomendasikan bahwa administrasi quickblood dan ultrafiltrasi dapat memberikan efek optimal pada nilai urea
\end{abstract}

Kata Kunci $\quad$ : Kecepatan Aliran Darah, Ultrafiltrasi, Ureum, Hemodialisis

\begin{abstract}
Patients with hemodialysis (HD) need to be assessed for their HD adhesions periodically. One parameter of adequation of HD action is to measure the values of Ureum to know the Ureum reduction ratio (URR). The purpose of this research is to know the relation of quick of blood $(Q B)$ and ultrafiltration $(U F)$ to urea value in hemodialysis patient at Klinik Khusus Hemodialisa Sahabat Keluarga. This study was conducted on 68 respondents (accidental sampling) using medical record data and written on the questionnaire. The result of the first measurement is known that the QB relations with ureum post $H D$ value has weak relation and negative pattern $(r=0,049)$, and P Value 0,034 $(\alpha 0,05)$, so it can be concluded that there is a $Q B$ relations to ureum value. In the second measurement analysis, the result of $Q B$ relationsh with ureum value of post $H D$ has a weak and negative correlation $(r=0,187)$, and the second measurement is $P$ value 0,127 ( $\alpha$ 0,05), so it can be concluded there is no relation of $Q B$ to value of ureum. The result of first measurement is known that UF relationship with ureum post HD value has weak relation and negative pattern $(r=0,220)$, and $P$ Value $0,071(\alpha 0,05)$ found no relation of UF to ureum value. In the second measurement, the result of UF relations with ureum value of post HD has moderate and negative relationship $(r=0,335)$, and the second measurement is $P$ value 0,005 ( $\alpha$ 0,05), It is recommended that the administration of quickblood and ultrafiltration can provide optimal effects on urea values.
\end{abstract}

Keywords : : Quick of blood, Ultrafiltrasi, Ureum, Hemodialysis 


\section{Pendahuluan}

Penyakit ginjal kronik (PGK) merupakan penurunan faal ginjal yang terjadi secara menahun dan umumnya bersifat irreversibel, ditandai dengan kadar ureum dan kreatinin yang sangat tinggi. ${ }^{1}$ Gagal ginjal kronik (GGK) merupakan perkembangan gagal ginjal yang progresif dan lambat (biasanya berlangsung selama beberapa tahun), perjalanan penyakit ginjal stadium akhir hingga tahap terminal dapat bervariasi dari 2-3 bulan hingga 30-40 tahun.

Angka kejadian gagal ginjal di dunia secara global lebih dari 500 juta orang dan yang harus menjalani hemodialisa 10 ribu orang. Jumlah penderita gagal ginjal di Indonesia yang menjalani terapi hemodialisa tercatat 30.554 pasien dan 21.050 diantaranya merupakan pasien baru. ${ }^{2}$

Indonesia Renal Registry (IRR) mencatat ditahun 2015 jumlah tindakan HD rutin di Indonesia sebanyak 595.358 kali perbulan, di Provinsi Jawa Barat tercatat 247.484 kali perbulan ${ }^{2}$. Hemodialisa bekerja dengan cara kombinasi dari difusi dan ultrafiltrasi. Pasien menjalani terapi dialisis sepanjang hidupnya dua hingga tiga kali seminggu, sehingga perlu dilakukan pemantauan keefektifan terapi HD atau yang lebih dikenal dengan Adekuasi secara berkala. Survei awal dilakukan peneliti di Klinik Khusus Hemodialisa Sahabat Keluarga Depok di dapatkan data jumlah pasien pada bulan Januari tahun 2018 sebanyak 68 pasien yang terdiri dari 25 orang laki-laki dan 43 orang perempuan. Berdasarkan hasil observasi malalui medical record yang dilakukan peneliti, 10 dari 68 pasien rata-rata nilai RRU $63,7 \%$. Hasil penelitian lain menunjukan bahwa terdapat pengaruh yang signifikan antara pengaturan QB terhadapap nilai ultrafiltrasi Ureum. ${ }^{3}$

Berdasarkan latar belakang ini, peneliti tertarik untuk melakukan penelitian mengenai hubungan quick of blood (QB) dan ultrafiltrasi terhadap nilai ureum pada pasien hemodialisa di Klinik Khusus Hemodialisa Sahabat Keluarga.

\section{Metode}

Penelitian ini menggunakan metode penelitian deskriptif analitik dengan rancangan retrospektif yaitu menggunakan data medical record untuk data selama 6 bulan kebelakang selama dihemodialisis. Penelitian ini dilaksanakan di Klinik Khusus Hemodialisa Sahabat Keluarga Depok pada tanggal 4 Juni sampai dengan 23 Juni tahun 2018. Sampel dalam penelitian ini yaitu seluruh total populasi yang berjumlah 83 orang, dan yang memenuhi kriteria inklusi sebanyak 68 orang. Instrumen pengumpulan data dalam penelitian ini menggunakan alat ukur lembar observasi dan hasil laboratorium yang diambil dari rekam medis.

Data yang dianalisis dalam penelitian ini dikelompokan menjadi data yang di dapatkan dari hasil pengukuran pertama (1) dan data yang di dapatkan dari hasil pengukuran kedua (2). Data pengukuran pertama dilakukan dibulan Juli 2017 dan data pengukuran kedua dilakukan di bulan Januari 2018 setiap tahunnya oleh pihak pegawai Klinik Khusus Hemodialisa Sahabat Keluarga.

Dalam penyajian data ini setiap variabel yang diukur dua kali diberikan kode sebagai berikut: Dialyzer (D), Quick of Blood (QB), Ultrafiltrasi (UF), dan Ureum (UR). Selanjutnya data variabel-variabel tersebut diatas ditambahkan kode angka 1 (satu) untuk data yang didapat dari pengukuran pertama Dialyzer 1 (D1), Quick of Blood 1 (QB1), Ultrafiltrasi 1 (UF1),Ureum 1 (UR1)dan ditambahkan angka 2 (dua) untuk data yang didapat dari pengukuran keduaDialyzer 2 (D2), Quick of Blood 2 (QB2), Ultrafiltrasi 2 (UF2), dan Ureum 2 (UR2).

\section{Hasil Dan Pembahasan}

\section{Analisis Univariat}

Rata-rata usia responden adalah 50,074 atau 50,1 tahun, dengan usia termuda yaitu 28 tahun dan yang tertua adalah 88 tahun. Hasil penelitian ini tidak jauh berbeda dengan penelitian Yuwono, Armiyati, dan Chanif yang menunjukkan bahwa rata-rata umur pasien HD adalah 48,2 tahun, dengan usia termuda 25 tahun dan yang tertua 78 tahun $^{3}$. Dalam penelitian Erwinsyah menyebutkan bahwa umur rata-rata dari sampel penelitiannya adalah 51,0 tahun. ${ }^{4}$

Salah satu faktor yang mempengaruhi penurunan fungsi ginjal adalah umur, hasil penelitiannya menunjukan umur penderita PGK di Jepang berkisar antara 18 - 70 tahun, penderita PGK di Jepang mengalami peningkatan jumlah pada usia diatas 50 tahun $^{5}$. 
Berdasarkan pemakaian ulang dialyzer yang digunakan saat dilakukan HD, dapat diketahui pada saat pengumpulan data pertama, rata-rata dialyzer yang digunakan 3,97 dengan pembulatan ke 4 atau dapat dikatakan dialyzer reuse ke 3. Pada pengumpulan data ke dua diketahui rata-rata responden menggunakan dialyzer ke 4,676 dengan pembulatan ke 5 atau reuse ke 4 . Dari data diatas juga dapat dilihat pemakaian terbanyak dialyzer hingga pemakaian ke 9, atau reuse ke 8 . Pemakaian reuse dialyzer di Indonesia telah dilakukan pada $92 \%$ pusat dialisis dengan rata-rata pakai ulang 2-10 kali dan dapat menghemat biaya $11-42 \%{ }^{6}$

Responden dalam penelitian ini didominasi oleh responden perempuan sebanyak $63,2 \%$. Perempuan dengan usia $>50$ tahun terjadi peningkatan resiko SM dibandingkan pria dengan kelompok umur yang sama. ${ }^{7}$ Perubahan siklus menopause pada wanita dikaitkan dengan peningkatan komponen SM seperti obesitas, hipertensi, perubahan dari profil lipid, dan hyperinsulinemia. ${ }^{8}$ Etiologi gagal ginjal kronik yang terbanyak yaitu lebih didominasi oleh hipertensi.

Berdasarkan tingkat pendidikan responden terbanyak adalah responden dengan tingkat pendidikan dasar sampai dengan pendidikan menengah keatas yaitu sebanyak $88,2 \%$.

Tabel 1. Gambaran karakteristik quick of blood (QB) dan ultrafiltrasi (UF) pasien hemodialisa di Klinik Khusus Hemodialisa Sahabat Keluarga $(n=68)$

\begin{tabular}{clccc}
\hline \multicolumn{2}{c}{ Kategori } & Mean & SD & $\begin{array}{l}\text { Min- } \\
\text { Max }\end{array}$ \\
\hline \multirow{2}{*}{ QB } & QB1 (Juli & 204,118 & 16,114 & $150-$ \\
& 2017) & & & 250 \\
\cline { 2 - 5 } & QB2 & 218,088 & 17,191 & $180-$ \\
& (Jan.2018) & & & 280 \\
\hline \multirow{2}{*}{ UF } & UF1 (Juli & 3,137 & 0,847 & $0,70-$ \\
& 2017) & & & 4,5 \\
\cline { 2 - 5 } & UF2 & 3,225 & 0,803 & $1,00-$ \\
& $(J a n .2018)$ & & & 4,00 \\
\hline
\end{tabular}

Berdasarkan tabel diatas dari 68 responden dalam penelitian ini dapat diketahui rata-rata nilai $\mathrm{QB}$ pada pengumpulan pertama adalah 204,118 ml/menit dengan QB minimal $150 \mathrm{ml} / \mathrm{menit}$ dan QB maksimal $250 \mathrm{ml} /$ menit.
Pada pengumpulan data kedua, diketahui ratarata QB adalah 218,088 $\mathrm{ml} /$ menit dengan QB minimal $180 \mathrm{ml} /$ menit dan QB maksimal 280 $\mathrm{ml} / \mathrm{menit}$. Data yang didapatkan saat pengumpulan data pertama menunjukan ratarata nilai UF yang digunakan adalah 3,137 $\mathrm{ml} /$ menit, dengan UF minimal $0,70 \mathrm{ml} /$ menit dan UF maksimal 4,5 ml/menit.

Pada pengumpulan data ke dua diketahui nilai rata-rata UF yang digunakan adalah $3,225 \mathrm{ml} / \mathrm{menit}$, dengan UF minimal 1,0 $\mathrm{ml} /$ menit dan UF maksimal 4,0 ml/menit. Pada saat hemodialisa dilakukan ultrafiltrasi untuk menarik cairan yang berlebihan di darah, besarnya ultrafiltrasi yang dilakukan tergantung dari penambahan berat badan penderita. Pasien yang menjalani terapi hemodialisa sebagian besar memiliki ultrafiltrasi rate dengan nilai $<10 \mathrm{ml} / \mathrm{kg} / \mathrm{jam}$ sebanyak 28 orang $(71,8 \%)^{9}$. UF yang lebih cepat pada pasien HD berhubungan dengan risiko yang lebih besar terhadap berbagai sebab kematian dan kematian karena $C V D^{10-11}$.

Tabel 2. Gambaran nilai ureum responden post HD Hemodialisa di Klinik Khusus Hemodialisa Sahabat Keluarga. $(n=68)$

\begin{tabular}{|c|c|c|c|c|c|}
\hline \multirow{2}{*}{$\begin{array}{l}\text { Kate } \\
\text { gori } \\
\text { Ureu }\end{array}$} & $\begin{array}{l}\text { Varia } \\
\text { bel }\end{array}$ & \multicolumn{2}{|c|}{ Mean } & SD & $\begin{array}{l}\text { Min- } \\
\text { Max }\end{array}$ \\
\hline & Ur1 & Pre & & & \\
\hline $\begin{array}{l}\mathrm{m} \\
(\mathrm{Ur})\end{array}$ & $\begin{array}{l}\text { (Juli } \\
\text { 2017) }\end{array}$ & $\begin{array}{l}131,64 \\
\text { Post } \\
33,058\end{array}$ & 33,059 & 11,950 & $\begin{array}{l}10,00- \\
67,00\end{array}$ \\
\hline & Ur2 & Pre & & & \\
\hline & $\begin{array}{l}\text { (Jan. } \\
\text { 2018) }\end{array}$ & $\begin{array}{l}147,75 \\
\text { Post } \\
34,015\end{array}$ & 34,015 & 14,887 & $\begin{array}{l}10,00- \\
82,00\end{array}$ \\
\hline
\end{tabular}

Pengumpulan data pertama didapatkan nilai rata-rata ureum setelah HD adalah 33,059 $\mathrm{mg} / \mathrm{dl}$, nilai ureum terendah adalah 10,00 $\mathrm{mg} / \mathrm{dl}$ dan tertinggi adalah 67,00 mg/dl. Sedangkan pada pengukuran ke dua didapatkan data rata-rata nilai ureum setelah HD adalah $34,015 \mathrm{mg} / \mathrm{dl}$, dengan nilai ureum terendah $10,00 \mathrm{mg} / \mathrm{dl}$ dan tertinggi adalah $82,00 \mathrm{mg} / \mathrm{dl}$.

\section{Analisis Bivariat}

Tabel 3. Hubungan quick of blood (QB) terhadap nilai ureum pada pasien hemodialisa di Klinik Khusus Hemodialisa Sahabat Keluarga. $(\mathrm{n}=68)$ 


\begin{tabular}{lccccc}
\hline QB & R & R2 & B & $\begin{array}{c}\text { Persamaan } \\
\text { Garis }\end{array}$ & $\begin{array}{c}\text { P } \\
\text { Value }\end{array}$ \\
\hline Pengukuran & 0,049 & 0,002 & 0,037 & Ur $=40,523$ & 0,034 \\
I & & & & + & \\
(Juli 2017) & & & & $0,037^{*} \mathrm{QB}$ & \\
\hline Pengukuran & 0,187 & 0,035 & 0,159 & $\mathrm{Ur}=0,537+$ & 0,127 \\
II & & & & $0,159^{*} \mathrm{QB}$ & \\
(Jan 2018) & & & & & \\
\hline
\end{tabular}

Analisis hasil pengukuran pertama diketahui hubungan QB dengan nilai ureum post HD memiliki hubungan yang lemah dan berpola negative $(r=0,049)$, dapat dimaknai bahwa semakin tinggi QB maka semakin banyak ureum yang dapat dikeluarkan, sehingga nilai ureum dalam darah pada saat pengukuran post HD semakin rendah. Hal ini sesuai dengan hasil penelitian lain yang menunjukkan bahwa rata-rata penurunan ureum tertinggi adalah pada QB $200 \mathrm{ml} / \mathrm{menit}$ yaitu sebesar $112,1 \mathrm{mg} / \mathrm{dl} .{ }^{1}$

Nilai maksimal penurunan ureum tertinggi juga terjadi pada QB $200 \mathrm{ml} /$ menit yaitu sebesar 160,4 mg/dl. Selain itu juga didapatkan P Value 0,034 ( $\alpha$ 0,05), sehingga dapat disimpulkan bahwa ada hubungan QB terhadap nilai ureum. Penelitian yang sama menjelaskan semakin tinggi QB maka RRU semakin tinggi yang artinya semakin banyak ureum yang terbuang, QB yang paling berpengaruh adalah QB $200 \mathrm{ml} /$ menit $^{1}$. Terdapat pengaruh yang signifikan antara pengaturan QB terhadapap nilai Ureum.

Analisis pengukuran kedua didapatkan hasil hubungan QB dengan nilai ureum post HD memiliki hubungan yang lemah dan berpola negative $(\mathrm{r}=0,187) .{ }^{1}$ Dengan demikian dapat dimaknai bahwa semakin tinggi QB maka semakin banyak ureum yang dapat dikeluarkan, sehingga nilai ureum dalam darah pada saat pengukuran post HD semakin rendah.

Rata-rata penurunan ureum tertinggi adalah pada QB $200 \mathrm{ml} /$ menit yaitu sebesar $112,1 \mathrm{mg} / \mathrm{dl} .{ }^{1}$ Nilai maksimal penurunan ureum tertinggi juga terjadi pada QB 200 $\mathrm{ml} /$ menit yaitu sebesar $160,4 \mathrm{mg} / \mathrm{dl}$. Pada analisis pengukuran ke dua didapatkan $\mathrm{P}$ Value sebesar $0,127 \quad(\alpha 0,05)$, sehingga dapat disimpulkan tidak ada hubungan QB terhadap nilai ureum. Hasil penelitian lain menyimpulkan bahwa tidak ada hubungan antara $\mathrm{QB}$ dengan penurunan ureum post $\mathrm{HD}$ pada pasien CKD yang menjalani HD (
PValue $=0,799)$, hasil ini dapat disebabkan oleh cara pengaturan $\mathrm{Qb}$, jenis dialyzer yang diguanakan belum sesuai standar ${ }^{4}$. Sejalan dengan penelitin lain yang menunjukan tidak ada hubungan bermakna antara QB dengan adekuasi Hemodialisa dengan $\mathrm{P}$ value = $0.225 .^{11}$

Pada saat dilakukan pengumpulan data, dari hasil wawancara dengan petugas diketahui akses pada responden berbeda-beda ada yang memakai akses AV Shunt dan chateter double lumen (CDL). Responden yang menggunakan akses AV Shunt dalam proses penusukan ada dua jarum yang digunakan inlet dan outlet. Inlet adalah jarum yang di hubungkan dengan pembuluh daran vena dan arteri ( $A V$ Shunt $)$ dan outlet adalah jarum yang di hubungkan dengan pembuluh darah vena.

Jarak antara jarum inlet dan outlet minimal $7 \mathrm{~cm}$ guna untuk mengurangi terjadinya resiko resirkurlasi dimana darah yang akan di dialisis tidak menyeluruh. Demikian juga halnya dengan akses CDL ada inlet dan outlet, selang CDL yang digunakan inlet lebih pendek daripada selang outlet. Apabila saat inisiasi keliru dalam memasangkan selang CDL atau mendapatkan kendala akses saat terapi hemodialisa berlangsung maka beresiko resirkulasi. Pada saat pengambilan data tidak didapatkan keterangan yang didokumentasikan kondisi saat melakukan inisiasi baik $A V$ Shunt maupun CDL. Hal ini berpengaruh terhadap efektifitas kerja QB dalam mengeluarkan ureum. Jarak antara pengukuran pertama dan pengukuran kedua adalah enam bulan, dalam rentang waktu tersebut memungkinkan banyak hal yang mengalami perubahan, misalnya jalur akses maupun tipe akses yang berubah.

Tabel 4. Hubungan ultrafiltrasi (UF) terhadap nilai ureum pada pasien hemodialisa di Klinik Khusus Hemodialisa Sahabat Keluarga. $(\mathrm{n}=68)$

\begin{tabular}{lccclll}
\hline \multicolumn{1}{c}{ UF } & R & R2 & B & $\begin{array}{l}\text { Persamaan } \\
\text { Garis }\end{array}$ & $\begin{array}{c}\text { P } \\
\text { Value }\end{array}$ \\
\hline Pengukuran & 0,220 & 0,048 & 3,107 & Ur $=$ & 0,071 \\
I & & & & $23,313+$ & \\
(Juli 2017) & & & & $3,107^{*} \mathrm{UF}$ & \\
\hline Pengukuran & 0,335 & 0,112 & 6,101 & $\mathrm{Ur}$ & $=$ & 0,005 \\
II & & & & $14,470+$ & \\
(Jan 2018) & & & & $6,101^{*} \mathrm{UF}$ & \\
\hline
\end{tabular}

Analisis hasil pengukuran pertama diketahui hubungan UF dengan nilai ureum post HD memiliki hubungan yang lemah dan 
berpola negative $(r=0,220)$. Selain itu juga didapatkan P Value 0,071 ( $\alpha$ 0,05), sehingga dapat disimpulkan bahwa tidak ada hubungan UF terhadap nilai ureum. Analisis pengukuran kedua didapatkan hasil hubungan UF dengan nilai ureum post HD memiliki hubungan yang sedang dan berpola negative $(r=0,335)$. Pada analisis pengukuran ke dua didapatkan $\mathrm{P}$ Value sebesar 0,005 ( $\alpha$ 0,05), sehingga dapat disimpulkan bahwa ada hubungan UF terhadap nilai ureum.

Pada saat hemodialisa dilakukan ultrafiltrasi untuk menarik cairan yang berlebihan di darah, besarnya ultrafiltrasi yang dilakukan tergantung dari penambahan berat badan penderita. Ultrafiltrasi rata-rata yang nilainya terlampau tinggi biasanya akan mengakibatkan komplikasi kardiovaskular, dengan demikian ultrafiltrasi dinyatakan baik bila memenuhi standar 10-13 $\mathrm{ml} / \mathrm{menit}$.

Pada saat pengukuran dilakukan, berdasarkan hasil wawancara dengan petugas dilapangan pada beberapa responden tidak dilakukan pengukuran berat badan dengan menggunakan timbangan berat badan $(\mathrm{kg})$ sebelum dan sesudah menjalani terapi hemodialisa, karena alasan kesulitan mobilisasi dan kondisi fisik responden. Untuk menentukan Ultrafiltrasi pada saat terapi hemodialisa berlangsung ditinjau dari peningkatan volume cairan yang dimanifestasikan dengan peningkatan berat badan sebagai indikator untuk mengetahui jumlah cairan.

Hal ini berpengaruh dalam menentukan ultrafilrasi. Berat badan kering merupakan berat badan ideal responden. Untuk menentukan berat badan kering harus melalui beberapa kali observasi dalam menjalani terapi hemodialisa. Responden yang baru melakukan terapi hemodialisa belum mendapatkan berat badan kering sedangkan untuk responden yang sudah lama menjalani terapi hemodialisa sudah mendapatkan berat badan kering. Hal ini sangat berpengaruh dalam menentukan ultrafiltrasi.

Jarak antara pengukuran pertama dan pengukuran kedua adalah enam bulan, dalam rentang waktu tersebut memungkinkan banyak hal yang mengalami perubahan, misalnya jalur akses maupun tipe akses yang berubah, kondisi kemampuan fisik secara umum yang menurun, sehinga ultrafiltrari tidak dapat dilakukan dengan maksimal sesuai kenaikan berat badan.
Tabel 5. Hubungan usia, jenis kelamin, pendidikan, pekerjaan terhadap nilai ureum pada pasien hemodialisa di Klinik Khusus Hemodialisa Sahabat Keluarga. $(n=68)$

\begin{tabular}{|c|c|c|c|c|c|}
\hline Usia & $\mathrm{R}$ & R2 & B & $\begin{array}{c}\text { Persamaa } \\
\text { n Garis }\end{array}$ & $\begin{array}{c}\mathrm{P} \\
\text { Value }\end{array}$ \\
\hline $\begin{array}{l}\text { Pengukuran } \\
\text { I } \\
\text { (Juli 2017) }\end{array}$ & $\begin{array}{l}0,23 \\
9\end{array}$ & 0,57 & $\begin{array}{l}0,24 \\
2\end{array}$ & $\begin{array}{l}\mathrm{Ur}= \\
45,918+ \\
0,242 * \mathrm{Usi}_{\mathrm{i}}\end{array}$ & 0,050 \\
\hline $\begin{array}{l}\text { Pengukuran } \\
\text { II (Jan 2018) }\end{array}$ & $\begin{array}{l}0,09 \\
7\end{array}$ & $\begin{array}{l}0,00 \\
9\end{array}$ & $\begin{array}{l}0,12 \\
1\end{array}$ & $\begin{array}{l}\text { Ur }= \\
40,213+ \\
0,212 * \text { Usi. } \\
\text { a. }\end{array}$ & 0,249 \\
\hline
\end{tabular}

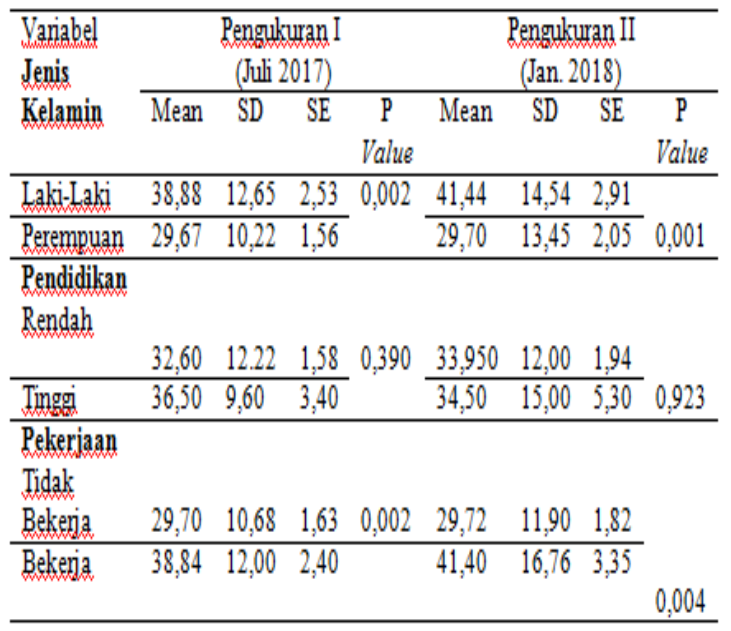

Analisis hasil pengukuran pertama diketahui hubungan usia dengan nilai ureum post HD memiliki hubungan yang lemah dan berpola negative $(r=0,239)$. Selain itu juga didapatkan $\mathrm{P}$ Value $0,05(\alpha$ 0,05), sehingga dapat disimpulkan bahwa ada hubungan usia terhadap nilai ureum. Proses penuaan atau bertambahnya umur sesorang akan menurunkan fungsi biologik dari semua organ yang ada. Semakin bertambahnya umur maka akan menambah resiko terjadinya suatu gangguan organ tubuh. ${ }^{12}$ Salah satu faktor yang mempengaruhi penurunan fungsi ginjal adalah umur 5 .

Analisis pengukuran kedua didapatkan hasil hubungan usia dengan nilai ureum post HD memiliki hubungan yang lemah dan berpola negative $(\mathrm{r}=0,097)$. Pada analisis pengukuran ke dua juga didapatkan $\mathrm{P}$ Value sebesar 0,249 $(\alpha$ 0,05), sehingga dapat disimpulkan bahwa tidak ada hubungan usia terhadap nilai ureum. Sejalan dengan penelitian yang lain menunjukan bahwa tidak ada hubungan yang bermakna antara umur dengan adekuasi hemodialisa ( $\mathrm{P}$ Value 0,479$)$, selain itu juga didapatkan nilai $r=0,142$ yang 
menunjukan hubungan yang lemah antara umur dengan adekuasi HD. ${ }^{11}$

Kesimpulan hasil analisis data pengukuran pertama ada hubungan antara usia dengan nilai ureum dan berpola negative pada pasien hemodialisa di Klinik Khusus Hemodialisa Sahabat Keluarga. Pengukuran ke dua yaitu usia dengan nilai ureum post HD memiliki hubungan yang lemah dan berpola negative dan tidak ada hubungan usia terhadap nilai ureum pada pasien hemodialisa di Klinik Khusus Hemodialisa Sahabat Keluarga.

Hasil Analisis data pengukuran pertama diketahui nilai rata-rata ureum post $\mathrm{HD}$ pada 25 responden laki-laki adalah $38,88 \mathrm{mg} / \mathrm{dl}$, sedangkan pada 43 responden perempuan nilai rata-rata ureum post $\mathrm{HD}$ adalah $29,67 \mathrm{mg} / \mathrm{dl}$. Hasil analisis tersebut menunjukan bahwa responden perempuan memiliki nilai ureum post HD relatif lebih rendah dibandingkan dengan responden laki-laki. Hasil ini juga menunjukan ada bubungan jenis kelamin terhadap nilai ureum yang ditunjukan oleh $\mathrm{P}$ Value 0,002 .

Hasil analisis data pengukuran kedua diketahui rata-rata ureum post $\mathrm{HD}$ pada 25 responden laki-laki adalah 41,44 $\mathrm{mg} / \mathrm{dl}$, sedangkan pada 43 responden perempuan nilai rata-rata ureum post $\mathrm{HD}$ adalah $29,70 \mathrm{mg} / \mathrm{dl}$. Hasil analisis tersebut menunjukan bahwa responden perempuan memiliki nilai ureum post HD relatif lebih rendah dibandingkan dengan responden laki-laki. Hasil ini juga menunjukan ada hubungan jenis kelamin terhadap nilai ureum yang ditunjukan oleh $\mathrm{P}$ Value 0,001 .

Kesimpulan hasil analisis data pengukuran pertama dan pengukuran ke dua yang menghubungkan jenis kelamin dengan nilai ureum, dapat disimpulkan bahwa ada hubungan jenis kelamin terhadap nilai ureum pada pasien hemodialisa di Klinik Khusus Hemodialisa Sahabat Keluarga. Hal ini sesuai dengan hasil penelitian Dewi (2010) yang menunjukan ada hubungan bermakna antara jenis kelamin responden dengan adekuasi HD dimana P Value $=0,0005$.

Anatomi saluran kemih laki-laki lebih panjang dari perempuan, saluran kemih yang penjang memungkinkan terjadinya pengendapan zat-zat yang terkandung dalam urin. Penderita PGK di Jepang lebih banyak laki-laki, hal ini karena perempuan mempunyai gaya hidup yang lebih sehat dari laki-laki ${ }^{5}$.
Pasien wanita cenderung memiliki kepatuhan yang lebih baik jika dibandingkan dengan pasien laki-laki sehingga kejadian komplikasi pada pasien perempuan lebih rendah ${ }^{13}$. Sehingga dapat disimpulkan baik secara anatomi tubuh maupun respon sikap dan perilaku pada laki-laki dan perempuan memiliki perbedaan yang memungkinkan mempengaruhi nilai ureum.

Hasil analisis data pada pengukuran pertama diketahui nilai rata-rata ureum pada 68 responden dengan pendidikan rendah adalah $32,60 \mathrm{mg} / \mathrm{dl}$, sedangkan pada 8 responden dengan pendidikan tinggi nilai rata-rata nilai ureumnya $36,50 \mathrm{mg} / \mathrm{dl}$, dengan $\mathrm{P}$ value 0,390 sehingga dapat disimpulkan bahwa tidak ada hubungan antara pendidikan responden dengan nilai ureum.

Pada pengukuran kedua didapatkan nilai rata-rata ureum pada responden dengan pendidikan rendah adalah $33,950 \mathrm{mg} / \mathrm{dl}$, sedangkan pada responden dengan pendidikan tinggi nilai rata-rata nilai ureum nya 34,50 $\mathrm{mg} / \mathrm{dl}$, dengan $\mathrm{P}$ value 0,923 sehingga dapat disimpulkan bahwa tidak ada hubungan antara pendidikan responden dengan nilai ureum. Kesimpulan hasil analisis data pengukuran pertama dan pengukuran ke dua yang menghubungkan pendidikan dengan nilai ureum, dapat disimpulkan bahwa tidak ada hubungan pendidikan terhadap nilai ureum pada pasien hemodialisa di Klinik Khusus Hemodialisa Sahabat Keluarga.

Pasien yang berpendidikan tinggi $(\geq \mathrm{D} 3)$ memiliki tingkat kepatuhan lebih tinggi yaitu $74,3 \%{ }^{14}$ Semakin lama pasien menjalani hemodialisa kemungkinan banyak mendapatkan pendidikan kesehatan dari perawat atau dokter tentang pentingnya melaksanakan hemodialisa secara teratur. sehingga pasien semakin patuh untuk menjalani terapinya. ${ }^{15}$

Hasil analisis data pada pengukuran pertama diketahui nilai rata-rata ureum pada 43 responden yang tidak bekerja adalah 29,70 $\mathrm{mg} / \mathrm{dl}$, sedangkan pada 25 responden yang bekerja nilai rata-rata nilai ureum nya 38,84 $\mathrm{mg} / \mathrm{dl}$, dengan $\mathrm{P}$ value 0,002 sehingga dapat disimpulkan bahwa ada hubungan antara pendidikan responden dengan nilai ureum. Pada pengukuran kedua didapatkan nilai ratarata ureum pada responden yang tidak bekerja adalah 29,72 mg/dl, sedangkan pada responden yang bekerja nilai rata-rata nilai ureumnya $41,40 \mathrm{mg} / \mathrm{dl}$, dengan $\mathrm{P}$ value 0,004 
sehingga dapat disimpulkan bahwa ada hubungan antara pekerjaan responden dengan nilai ureum.

Berdasarkan analisis data pengukuran pertama dan pengukuran ke duadisimpulkan bahwa ada hubungan pekerjaan terhadap nilai ureum pada pasien hemodialisa di Klinik Khusus Hemodialisa Sahabat Keluarga. Pasien yang menjalani hemodialisa mengalami penurunan fungsi fisik berupa ketidak mampuan menjalankan pekerjaan seperti sedia kala. Hasil observasi menunjukan responden yang masih bekerja sebagian besar adalah Pegawai Negri Sipil dan Wiraswasta. Pekerjaan pada laki-laki cenderung lebih berat yang terkadang membuat laki-laki mengkonsumsi minuman suplemen berlebihan sehingga memiliki kecenderungan lebih rentan terkena gagal ginjal kronik sehingga harus menjalani hemodialisa ${ }^{16}$.

Tabel 6. Hubungan dialyzer terhadap nilai ureum pada pasien hemodialisa di Klinik Khusus Hemodialisa Sahabat Keluarga. ( $\mathrm{n}=$ 68)

\begin{tabular}{lccccc}
\hline Dyalizer & R & R2 & B & $\begin{array}{c}\text { Persamaan } \\
\text { Ganss }\end{array}$ & $\begin{array}{c}\text { P } \\
\text { Value }\end{array}$ \\
\hline Pengukuran & 0,118 & 0,014 & 0,644 & $\mathrm{Ur}=35,614+$ & 0,339 \\
I & & & & $0,644^{*}$ Dyalizer & \\
(Juli 2017) & & & & & \\
\hline Pengukuran & 0,062 & 0,004 & 0,363 & $\mathrm{Ur}=32,451+$ & 0,616 \\
II & & & & $0,3633^{*}$ Dyalizer \\
(Jan 2018) & & & & & \\
\hline
\end{tabular}

Analisis hasil pengukuran pertama. diketahui hubungan Dialyzer dengan nilai ureum post HD memiliki hubungan yang lemah dan berpola negative $(\mathrm{r}=0,118)$. Selain itu juga didapatkan P Value 0,339 $(\alpha 0,05)$, sehingga dapat disimpulkan bahwa tidak ada hubungan dialyzer terhadap nilai ureum. Analisis pengukuran kedua didapatkan hasil hubungan dialyzer dengan nilai ureum post HD memiliki hubungan yang lemah dan berpola negative $(\mathrm{r}=0,062)$. Pada analisis pengukuran ke dua juga didapatkan $\mathrm{P}$ Value sebesar 0,616 ( $\alpha$ 0,05), sehingga dapat disimpulkan bahwa tidak ada hubungan dialyzer terhadap nilai ureum.

Kesimpulan hasil analisis data pengukuran pertama dan pengukuran ke dua yaitu dialyzer dengan nilai ureum memiliki hubungan yang lemah dan berpola negative dan tidak ada hubungan dialyzer terhadap nilai ureum pada pasien hemodialisa di Klinik Khusus Hemodialisa Sahabat Keluarga. Pemakaian ulang dialyzer sampai sebanyak 7 kali tidak mempengaruhi nilai URR $(p=0.944)$ dan Kt/V $(p=0.947)$ pada pasien hemodialisis kronik. $^{17}$

Nilai URR masih tetap adekuat (>65\%) sampai pemakaian ulang kesepuluh $(\mathrm{R} 10)^{18}$. Pada Negara Indonesia pemakaian ulang telah dilakukan pada $92 \%$ pusat dialisis dengan ratarata pakai ulang 2-10 kali dan dapat menghemat biaya $11-42 \%{ }^{6}$. Data dari The Hemodialysis (HEMO) Study Group menyebutkan bahwa terdapat penurunan urea clearance sebesar $1-2 \%$ setiap 10 kali pemakaian ulang dialyzer tanpa melihat jenis dialyzer maupun teknik reuse yang dipakai. ${ }^{19}$

\section{Kesimpulan}

Penelitian ini melihat penilaian QB, Ultrafiltrasi dan nilai uream dalam rentang 6 bulan pada pasien hemodialisis. Pada pengukuran pertama nilai rata rata $\mathrm{QB}$ : 204,118 ml/menit, ultarfiltrasi : $3,137 \mathrm{ml} /$ menit dan nilai ureum : $33,059 \mathrm{mg} / \mathrm{dl}$. Setelah 6 bulan dilihat kembali pengukuran kedua nilai rata rata QB : 218,088 $\mathrm{ml} /$ menit, ultrafiltrasi : 3,225 $\mathrm{ml} / \mathrm{menit}$ dan nilai ureum : $34,015 \mathrm{mg} / \mathrm{dl}$.

Keterkaitan antara nilai QB, UF dan nilai ureum dihasilkan bahwa Pada pengukuran pertama dan kedua didapatkan terdapat pengaruh yang signifikan antara pengaturan QB terhadap nilai ureum. Dengan demikian semakin tinggi QB maka semakin banyak ureum yang dapat dikeluarkan sehingga nilai ureum dalam darah pada saat pengukuran post HD semakin rendah. Pada ultrafiltrasi pada pengukuran kedua saja yang memiliki pengaruh yang signifikan terhadap nilai ureum. Jarak antara pengukuran pertama dan pengukuran kedua adalah enam bulan, dalam rentang waktu tersebut memungkinkan banyak hal yang mengalami perubahan, misalnya, kondisi kemampuan fisik secara umum yang menurun, sehinga ultrafiltrari tidak dapat dilakukan dengan maksimal sesuai kenaikan berat badan.

\section{Daftar Pustaka}

1. Rosida dan Arifin. Kadar Kreatinin Serum Sebelum Dan Sesudah Hemodialisis Pada Penderita Gagal Ginjal Terminal. Berkala 
Kedokteran. 2005; Vol. 4. No. 1.

2. Indonesian Renal Registry. $8^{\text {th }}$ Report Of Indonesian Renal Registri 2015. TIM Indonesian Renal Registry; 2015

3. Yuwono, I, H., Armiyati, Y., Chanif. Pengaturan Kecepatan Aliran Darah (Quick Of Blood) terhadap Rasio Resuksi Ureum pada Pasien Penyakit Ginjal Kronis Yang Menjalani Hemodialisis di Unit Hemodialisis RSUD Kota Semarang. Prosding Konferensi Nasional PPNI Jawa Tengah; 2013.

4. Erwinsyah. Hubungan antara Quick of Blood ( QB ) dengan Penurunan kadar Ureum dan Kreatin pada Pasien CKD yang Menjalani Hemodialisa di RSUD Mattaher Jambi. Jakarta. Universitas Indonesia; 2009

5. Iseki, K. Gender differences in chronic kidney disease. Kidney International. 2008; 74, 415417.

6. Ardaya, Ali , Effendi, Siregar. .Perbandingan analisis kesintasan 2 tahun antara pasien hemodialiss reuse dan tanpa reuse. Proceding KOPAPDI XI. Surabaya, Juli.

7. Bantas, K., Yosef, H.K., Moelyono, B. Perbedaan Gender pada Kejadian Sindrom Metabolik pada Penduduk Perkotaan di Indonesia. Jurnal Kesehatan Masyarakat Nasional.2012; 7(5), 3-8.

8. Carr, M.C., (2003). The emergene of metabolic syndrome with menopause. The journal of clinical Endocrinology and Metabolism. 2003; 88, 2404-11.

9. Putri, R.I.Faktor Determinan Nefropati Diabetik pada penderita Diabetes Mellitus di RSUD Dr. M. Soewandhie Surabaya. Jurnal Berkala Epidiomologi. 2015; 3(10): 109-121.

10. Flythe JE, Brunelli SM. The risk of high ultrafiltration rate in chronic hemodialysis:Implications for patient care. Sem Dialysis. 2011:259-65.

11. Dewi., I Gusti Ayu Puja Astuti. Hubungan Antara Quick Of Blood Dengan Adekuensi Hemodialisis Pada Pasien Yang Menjalani Terapi Hemodialisis Diruang HD RSU Daerah Tabanan Bali; 2010
12. Fowler,B. Functiona land Biological Markers of Aging. In:Klatz,R. Anti-Aging Medical Therapeutics. 2003; volume 5. Chicago : the A4M Publications. p.43.

13. Akrom, Akrom and Darmawan, Endang and Maulida N. Factors relate to the hypercreatininemia event of patients at risk of metabolic syndrome in Jetis I Public Health Center, Pharmaciana. 2017; 7 (2). pp. 205-216.

14. Sapri, A. Faktor-Faktor yang Mempengaruhi Kepatuhan Dalam Mengurangi Asupandr. H. Abdul Moeloek Bandar Lampung. 2004 Diakses 12 Februari 2018 dari http://www.indonesiannursing,com

15. Suryaningsih, Y. Hubungan Penambahan Berat Badan Antara Dua Waktu Dialisis Dengan Kualitas Hidup Pasien Hemodialisis Di Rumah Sakit Dr.M. Djamil Padang.Tesis. Depok : Universitas Indonesia; 2010

16. Istanti,Y.P. Hubungan Antara Masukan Cairan Dengan Interdialytic Weight Gain (IDWG) Pada Pasien Chronic Kidney Disease Di Unit Hemodialisis RS PKU Muhammadiyah Yogyakarta. Jurnal PROFESI. 2014; Volume 10/September 2013-Februari 2014.

17. Purnama, Y, I., Kandarini, Y., Sudhana., Loekman, J, S., Widiana, R., Suwitra,K. Pemakaian Ulang Dialiser Tidak Berpengaruh Terhadap Nilai Urea Reduction Rate dan KT/V Pada Pasien HemodialisisKronis; 2015

18. Armelia, L. Efektifitas pemakaian Ulang Ginjal Buatan. Department of Internal Medicine, YARSI UNIVERSITY School of Medicine, Jakarta; 2003

19. Twardowski ZJ. Dialyzer Reuse - Part II: Advantages and Disadvantages. Seminars in Dialysis. 2006; 19 (3): 217-226. 